\title{
INFLUENCE OF ENVIRONMENTAL FACTORS ON A HALODULE WRIGHTII ASCHERSON MEADOW IN NORTHEASTERN BRAZIL
}

\author{
Barros, K.V.S.* \& Rocha-Barreira, C.A. \\ Instituto de Ciências do Mar (Labomar),Universidade Federal do Ceará - Av. \\ Abolição, 3207, 60165-081 Fortaleza, CE, Brasil \\ *Corresponding author: kcrishna@gmail.com
}

\begin{abstract}
Barros, K.V.S. \& Rocha-Barreira, C.A. 2014. Influence of environmental factors on a Halodule wrightii Ascherson meadow in northeastern Brazil. Braz. J. Aquat. Sci. Technol. 18(2): 31-41. eISSN 1983-9057. DOI: 10.14210/bjast. v18n2.p31-41 The influence of environmental factors on the shape, biomass and biometry of Halodule wrightii was determined throughout the year, in Goiabeiras Beach (Fortaleza-Ceará-Brazil), based on the measurement of meadow shape and employing non-parametric Spearman correlations, canonical correlation analyses and BIO-ENV. Biomass and biometry of $H$. wrightii were significantly greater in the rainy season in comparison to the dry season. These characters were also positively correlated to variables associated with rainfall. Considering the main environmental factors analyzed, meteorological factors exert a greater influence on a number of variables. Besides waves, strongly influenced by winds in this area, temperature and salinity had a significant role on the variance found in the $H$. wrightii meadow studied, which can be related to sporadic exposition. Thus, further studies should consider the specific influence of these variables, and also what are the specific influences on reproductive events in $H$. wrightii in the natural environment.
\end{abstract}

Key Words: biomass, biometry, shoal grass, vegetative cycle.

\section{INTRODUCTION}

Seagrasses exert a significant influence on the coastal zone (Hemminga \& Duarte, 2000) and are therefore known as "ecosystem engineers" (Jones et al., 1994). In turn, environmental factors may influence the plasticity and life cycle of seagrasses (Marbà et al., 2004; Orth et al., 2006). Due to their sensitivity to environmental changes and the signaling of the loss of "ecosystem services", these plants are also recognized as "biological sentinels" or "coastal canaries" (Orth et al., 2006).

Studies have reported the effects of the following environmental factors on seagrass meadows: turbidity, that cause seagrass loss (Preen \& Marsh, 1995) due to physiological and morphological changes (Longstaff \& Dennison, 1999); hydrodynamic action of wind, inversely correlated to seagrass biomass (Rubegni et al., 2013), causing seagrass berm erosion (Simeone et al., 2013); current velocity, which may have either a positive or negative effect (Fonseca \& Kenworthy, 1987; Gambi et al., 1990; Koch \& Beer, 1996; Koch, 2001); waves, that alter both the plant morphology and other environmental characteristics (Clarke, 1987; Koch, 2001); light, the minimal decline of which can cause significant loss in terms of growth and distribution (Bulthuis \& Woelkerling, 1983; Koch, 2001), leaf size (Gordon et al., 1994), number of leaves per shoot (Ruiz \& Romero, 2001) and total shoot biomass (Dennison \& Alberte, 1985); temperature (Koch et al., 2007a; Masini et al., 1995); and salinity (Koch et al., 2007b).

Global climate changes may cause a chain reaction in this ecosystem by altering temperature, light, sea level, atmospheric $\mathrm{CO}_{2}$ and ultraviolet radiation. These changes, in turn, affect the distribution, productivity and composition of the seagrass community and consequently influence a number of coastal processes (Short \& Neckles, 1999; Duarte, 2002). The widespread distribution of seagrasses throughout tropical and temperate regions allows a better assessment of larger-scale trends in climate phenomena than other coastal habitats, such as mangroves, coral reefs or salt marsh plants, which are limited to only one of these broad geographic regions (Orth et al., 2006).

Studies on the effect of environmental factors on the lifecycle of these plants may help predict the future of the meadows, mainly considering the current effects of global climate changes, being essential to the understanding and mitigation of effects of these changes in coastal areas (Barros et al., 2013). However, rare information on environmental influences on vegetative and reproductive cycles of seagrasses in situ is available.

Observing studies in different regions along the Brazilian coast, differences in the lifecycle of seagrass species were evidenced, probably because of climate differences between regions (Barros et al., 2013). Halodule wrightii Ascherson is a tropical species found in most geographic bioregions in the global distribution of seagrasses (Short et al., 2007) and in Brazil is found from Pará (Northern Brazil) to Paraná (Southern Brazil) (Oliveira et al., 1983; Sordo et al., 2011; Rosa-Filho, J.S., pers. com.). The aim of the present study was to determine the influence of environmental factors on the vegetative cycle of $H$. wrightii in an area near the equator line. 


\section{MATERIAL AND METHODS}

\section{Study Area}

The study area was a reef rock formation of approximately 500 meters of extension containing macroalgae banks and a bed of $H$. wrightii off Goiabeiras Beach (0341'31"S; 038 34'49”W) in the state of Ceará, northeastern Brazil (Fig. 1). At low spring tides, the reefs and associated flora are fully exposed to the action of waves, solar radiation and air.

The climate is the Aw' type (rainy tropical with a long dry season) (Köppen, 1948). The rainy season occurs in first half of the year, mainly from February to May, and is related to the influence of the InterTropical Convergence Zone (Maia et al., 2001). In the subsequent months, precipitation decreases and wind velocity intensifies, reaching a peak between August and November (Morais, 1980). According to Morais et al. (2006), the area is bordered by the saline and oxygenated waters of the North Brazil Current, which is partially responsible for the northwesterly direction of the coastal currents, whereas longitudinal currents are primarily derived from the trade winds and the incidence of waves on the coastline. The authors also state that the tidal regimen of this region is semi-diurnal mesotidal and the waves vary among the E, E-NE and E-SE quadrants, with periods between four and seven seconds and wave height ranging from 0.8 to $1.5 \mathrm{~m}$.

\section{Field Sampling}

Sampling was performed monthly from April 2006 to July 2007 at low spring tides. The reduced area and regular emersion of the meadow during these tides allowed the observation of changes in meadow dimensions. Measurements of the meadow were sporadically performed throughout the study using a GPS device, compass and tape measure. These measurements were based on four points marked at the beginning of the study (April 2006), from which the following variables were determined: meadow length

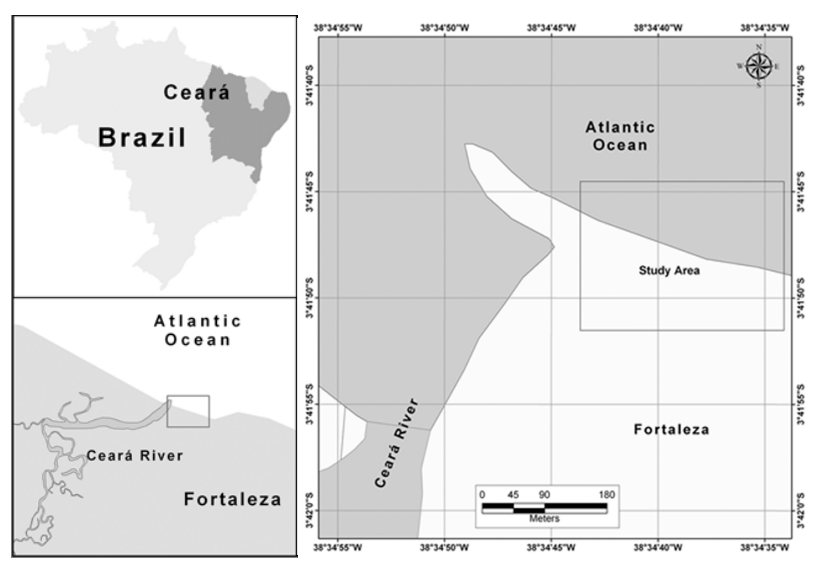

Figure 1 - Study area location. Goiabeiras Beach, Fortaleza, Ceará, Northeast of Brazil. (h), positioned perpendicular to the coastline; and three widths (central $[y]$ and marginal $[x$ and $z]$ ) parallel to the coastline (Fig. 2).

The sampling design was adapted from Burdick and Kendrick (2001) and considered one point of origin with seagrasses and four replicate samples ten meters from the point of origin (when possible) guided by the four cardinal directions (N, S, E and W), with a total of five samples at each sampling. Samples were collected using a PVC corer with a diameter of $10 \mathrm{~cm}$ buried at a depth of $10 \mathrm{~cm}$. The samples were preserved in a formalin solution and transported to the Institute of Marine Sciences of the Federal University of Ceará (Labomar/UFC).

Sediment samples were placed in tagged bags and processed at the Laboratory of Marine Geology of the Institute of Marine Sciences (Labomar/UFC). Water temperature, salinity and dissolved oxygen were determined in situ using a multiparameter probe. Precipitation indices, cloudiness, wind velocity, wave height and wave period variables were obtained from the Database for Teaching and Research of the Brazilian Institute of Meteorology - BDMEP (2006/2007). Low tide data were obtained from the Brazilian National Bank of Oceanographic Data of the Brazilian Navy (2006/2007). Monthly hours of total exposure of the meadow were estimated based on the occurrence of tides up to $0.1 \mathrm{~m}$, when the reefs were fully exposed (i.e. $0.1 \mathrm{~m}=00: 50 \mathrm{~h} ; 0.0 \mathrm{~m}=01: 20 \mathrm{~h} ;-0.1 \mathrm{~m}$ $=01: 40 \mathrm{~h}$ ). Monthly hours of sunlight were obtained from the Brazilian National Observatory.

For each monthly sampling, the length of one hundred randomly selected leaf samples was measured from petiole to apex using a digital caliper with a precision of $0.05 \mathrm{~mm}$. The samples of $H$. wrightii were dried at $60^{\circ} \mathrm{C}$ to obtain the biomass in grams of dry weight per square meter (g.dw. $\left.\mathrm{m}^{-2}\right)$.
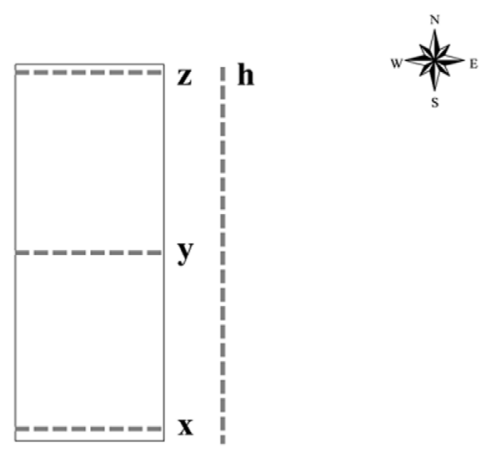

Coastline

Figure 2 - Position for the measurements established on the seagrass meadow in relation to the coastline, in Goiabeiras Beach, Ceará, Northeastearn Brazil. Legend: $\mathrm{h}$ - meadow lenght; $\mathrm{y}$-central width; $x$ and $z$ - marginal widths. 


\section{Statistical Analyses}

Using the Euclidean distance of the dataset of abiotic variables, groups of samples were formed based on affinity to the dry or rainy season. These groups were used for further analyses of comparison between seasonal averages (t-test). The influence of environmental variables on $\mathrm{H}$. wrightii was determined based on changes in meadow dimensions ( $\mathrm{h}, \mathrm{x}, \mathrm{y}$ and z) throughout the study and using non-parametric Spearman correlations, Canonical Correlation Analysis (CCA) and BIO-ENV analysis. Spearman correlation coefficients were calculated to determine associations among environmental variables. CCA was employed to determine interactions among environmental variables and $H$. wrightii characters. For this analysis, non-correlated data were log-transformed prior to the CCA calculations, focusing on inter-sample distance. BIO-ENV was employed to identify the environmental variables that best explained the variation in the $H$. wrightii characters throughout the year. Euclidean distances and BIO-ENV were performed using Plymouth Routines in Multivariate Ecological Research (Primer ${ }^{\circledR}$, 6.1.6 version). Spearman's rank correlation coefficients and variances were determined using the Statistica ${ }^{\circledR}$ program (7.0 version). CCA was obtained using the CANOCO program for Windows (4.5 version).

\section{RESULTS}

\section{Environmental variations}

The Euclidean distance cluster (Fig. 3) of the environmental dataset indicated two groups of samples: one associated with the rainy season (February to May 2006 and 2007; June 2006) and another one (more homogeneous) group associated with periods of decreased precipitation and an increase in wind velocity (July 2006 to January 2007; June and July 2007).
Therefore, seasonal fluctuations in physicochemical and sedimentary variables seemed governed by precipitation and wind velocity, as both factors exerted an influence on a number of these variables.

Precipitation indices increased progressively from January to April, reaching a peak in March and April decreasing from May to November. The smallest index was recorded in November $2006(2.7 \mathrm{~mm})$ and the highest was recorded in April 2006 (398mm). Indices of cloudiness were smaller between July/06 (4,5 days) to November/06 (5,4 days) and higher in rainy months (February to May), when reached average rates near to 8 days (May/06). Winds had a predominantly east-southeast (ESE) direction. The lowest velocity was recorded in April $2006(3.85 \mathrm{~m} / \mathrm{s})$ and the highest was recorded in September $2006(7.34 \mathrm{~m} / \mathrm{s})$. Low tide averages $(0.57 \mathrm{~m}$ and $0.61 \mathrm{~m})$ and hours of total exposure of the meadow $(0.98 \mathrm{~h}$ and $0.83 \mathrm{~h})$ were higher during the dry season. Sunlight hours were greater between August (12h) and April (12h), with a peak between November and January (12.3h). Mean duration of sunlight in the remaining months was $11.9 \mathrm{~h}$.

Temperature varied from $27^{\circ} \mathrm{C}$ (June 2006) to $32.6^{\circ} \mathrm{C}$ (May 2007), and salinity, from 25 (April 2007) to 40 (December 2006) but both did not have significant seasonal variations. Variations in mean monthly waves height and dissolved oxygen content were similar to the variation in wind velocity throughout the year. The smallest mean waves height occurred in April 2006 and April 2007 (both 1.5m) and the highest means occurred in September 2006 and October 2006 (both $1.9 \mathrm{~m})$. The least amount of dissolved oxygen occurred in January $2007(2.4 \mathrm{mg} / \mathrm{l})$ and the highest amount occurred in July $2006(12.9 \mathrm{mg} / \mathrm{l})$.

Regarding the sediment, the grain was generally well selected to moderately selected. Grain size characterized the sediment of the meadow as fine sand. However, larger fractions of medium sand were found

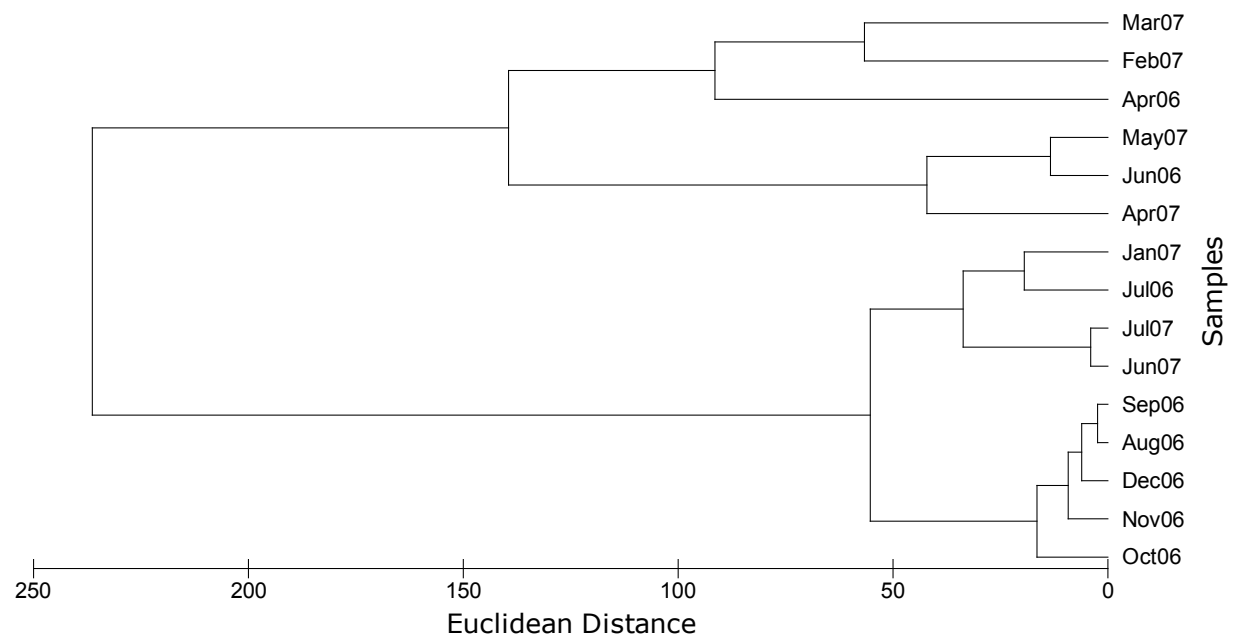

Figure 3 - Euclidean Distance dendrogram based on abiotic variables obtained for Goiabeiras Beach, Ceará, Northeastern Brazil. 
in some dry months (September and October 2006). Organic matter content was lower in the dry season $(0.96 \%)$ and greater in the rainy season $(1.45 \%)$.

Although greater in the rainy season, cloudiness, wave period, emersion hours, temperature and gravel percentages did not differ significantly between the two seasons (Table 1). Likewise, mean wind velocity, wave height, low tides, salinity, dissolved oxygen and sandy percentage were greater in the dry season, but the differences between seasons did not achieve statistical significance (Table 1). Precipitation indices were correlated to percentages of fine sand. Wind velocity was especially correlated to sunlight hours, probably because their indices increase during the same season (Table 1). Significant differences between seasons were only found with regard to precipitation, days of precipitation, sunlight hours, percentage of fine sand and OM content (Table 1).

Based on Spearman' correlation coefficients and seasonal means of the variables, precipitation and wind velocity may have exerted a significant influence on different groups of variables (Table 2).

\section{Seasonal variations in Halodule wrightii}

The vegetative cycle of the seagrass studied tends to begin with the onset of the rainy season, when the leaves grow and the biomass increases. Both characters reach peak values at the apex of the rainy season and decrease with the action of the winds around the middle of the dry season. The leaves grow again with the first rains of the following year (Fig. 4).

In absolute terms, mean leaf length and biomass exhibited a similar seasonal pattern. Mean leaf length was $9.6 \mathrm{~cm}$ at the apex of the rainy season and $6.2 \mathrm{~cm}$ at the end of the dry season, with averages of $11.1 \pm 2.5 \mathrm{~cm}$ in the rainy season and $8.4 \pm 2.4 \mathrm{~cm}$ in the dry season. The total biomass reached $28.2 \mathrm{~g} . \mathrm{dw} \cdot \mathrm{m}^{-2}$ during the rainy season and $6.3 \mathrm{~g} \cdot \mathrm{dw} \cdot \mathrm{m}^{-2}$ at the apex of the dry season, reaching averages of $656.1 \pm 2.4 \mathrm{~g}$. $\mathrm{dw} . \mathrm{m}^{-2}$ in the rainy season and $497.5 \pm 5 \mathrm{~g} . \mathrm{dw} \cdot \mathrm{m}^{-2}$ in the dry season.

Mean aboveground biomass was $48.6 \pm 4.1 \mathrm{~g}$. $\mathrm{dw} \cdot \mathrm{m}^{-2}$ and $69.1 \pm 5.2 \mathrm{~g} . \mathrm{dw} \cdot \mathrm{m}^{-2}$; mean belowground biomass was $448.9 \pm 1.2 \mathrm{~g} . \mathrm{dw} \cdot \mathrm{m}^{-2}$; and $586.9 \pm 1 . \mathrm{g} . \mathrm{dw} . \mathrm{m}^{-2}$, for dry and rainy seasons, respectively. In general, the belowground compartment accounted for $88.7 \%$ of the total biomass. The aboveground compartment accounted for $11.8 \%$ of the total biomass in the dry season and $10.6 \%$ in the rainy season. Mean total biomass $(t=2.305 ; d f=63 ; p=0.024)$, belowground biomass $(t=2.040 ; d f=63 ; p=0.004)$ and leaf length $(t=2.640 ; d f=63 ; p=0.010)$ differed significantly between seasons, whereas no statistically significant differences were found regarding the aboveground biomass $(t=2.305 ; d f=63 ; p=0.063)$.

\section{Influence of environmental factors on the Halodule wrightii shape}

The reduction in biometry and biomass occurred simultaneously to the increase in wind velocity, when also was observed great leaves at the drift line, clearing into the meadow, roots and rhizomes exposure (mainly at the edges), and the burying of shallower parts of the meadow.

The length (h) of the $H$. wrightii bed studied was greatest in August 2006 (31.2 m). However, throughout most of the study, the widths ( $x, y$ and $z$ ) were greater than the length (h) (Fig. 5). The "y" width had the greatest values, which ranged from $13.2 \mathrm{~m}$ (April 2006) to $30.8 \mathrm{~m}$ (May 2007). The marginal " $x$ " width, which was farthest from coastline, ranged from $9.2 \mathrm{~m}$ (November

Table 1 - Parametric variances of environmental variables obtained throughout the study in Goiabeiras Beach, Northeastern Brazil. $\left({ }^{*}\right)$ Variables significantly different between seasons.

\begin{tabular}{lrrrrr}
\hline \hline \multirow{2}{*}{ Variables } & \multicolumn{2}{c}{ Mean } & \multirow{2}{*}{ t } & df & p \\
\hline Precipitation (mm/month) & \multicolumn{1}{c}{ Rainy } & & & \\
Days of Precipitations & 8.200 & 234.620 & 3.336 & 11 & $0.007^{*}$ \\
Cloudiness & 5.225 & 18.200 & 3.111 & 11 & $0.010^{*}$ \\
Windy velocity (m/s) & 2.913 & 2.140 & -1.430 & 11 & 0.181 \\
Waves height (m) & 1.851 & 1.768 & -1.233 & 11 & 0.243 \\
Waves period (s) & 7.408 & 8.015 & 0.909 & 11 & 0.383 \\
Sunlight hours (h) & 274.025 & 163.660 & -4.622 & 11 & $0.001^{*}$ \\
Low tides (m) & 0.608 & 0.600 & -0.234 & 11 & 0.819 \\
Emersion Hours & 0.896 & 1.167 & 0.909 & 11 & 0.383 \\
Temperature ( $\left.{ }^{\circ} \mathrm{C}\right)$ & 26.784 & 27.114 & 1.092 & 11 & 0.298 \\
Salinity (ppm) & 36.676 & 35.840 & -0.721 & 11 & 0.486 \\
Dissolved Oxygen (mg/l) & 6.535 & 4.700 & -1.121 & 11 & 0.286 \\
Gravel (\%) & 2.132 & 2.374 & 0.126 & 11 & 0.902 \\
Sandy (\%) & 97.618 & 96.036 & -0.826 & 11 & 0.427 \\
Fines (\%) & 0.252 & 1.589 & 3.318 & 11 & $0.007^{*}$ \\
OM (\%) & 0.944 & 1.522 & 4.060 & 11 & $0.002^{*}$ \\
\hline \hline
\end{tabular}


Table 2 - Spearman's rank correlations (R) of the environmental variables studied at Goiabeiras Beach, northeastern Brazil. Legend: PP - pluviometric precipitations; Cd - cloudiness; WV - Wind Velocity; WH - wave height; WP - wave period; SH - sunlight hours; LT - low tides; EH - emersion hours; Tp - temperature; SI - salinity; DO - dissolved oxygen; Gr - gravel percentage; Sd - sandy percentage; Fn - fines percentage; OM - organic matter content. $\left(^{*}\right)$ variables significantly correlated $(p<0.05)$

\begin{tabular}{|c|c|c|c|c|c|c|c|c|c|c|c|c|c|c|c|}
\hline & $\overline{P P}$ & $\overline{C d}$ & $\overline{\text { WV }}$ & $\overline{\mathrm{WH}}$ & $\overline{\text { WP }}$ & $\overline{\mathrm{SH}}$ & 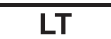 & $\overline{E \mathrm{EH}}$ & $\overline{\overline{T p}}$ & $\overline{\text { SI }}$ & $\overline{\text { DO }}$ & $\overline{\mathrm{Gr}}$ & $\overline{\text { Sd }}$ & $\overline{F n}$ & $\overline{O M}$ \\
\hline$\overline{\mathbf{P P}}$ & 1 & 0.308 & -0.462 & -0.503 & 0.098 & $-0.818^{*}$ & 0.499 & -0.354 & 0.119 & -0.532 & -0.233 & 0.098 & -0.245 & $0.780^{*}$ & 0.280 \\
\hline Cd & & 1 & -0.462 & $-0.650^{*}$ & -0.035 & $-0.720^{*}$ & 0.411 & -0.254 & 0.161 & -0.053 & -0.550 & -0.056 & 0.070 & 0.086 & 0.147 \\
\hline WV & & & 1 & 0.497 & -0.155 & $0.663^{*}$ & -0.124 & -0.042 & -0.236 & 0.166 & -0.050 & 0.053 & -0.028 & -0.559 & -0.511 \\
\hline WH & & & & 1 & 0.315 & $0.748^{*}$ & $-0.654^{*}$ & $0.655^{*}$ & 0.126 & 0.077 & 0.067 & 0.238 & 0.084 & -0.304 & -0.259 \\
\hline WP & & & & & 1 & 0.007 & $-0.636^{*}$ & $0.580^{*}$ & $0.615^{*}$ & -0.137 & -0.650 & $0.629^{*}$ & 0.629 & 0.226 & -0.224 \\
\hline SH & & & & & & 1 & -0.538 & 0.329 & -0.280 & 0.326 & 0.433 & -0.105 & 0.259 & $-0.585^{*}$ & -0.441 \\
\hline LT & & & & & & & 1 & $0.601^{*}$ & -0.566 & -0.236 & 0.142 & -0.362 & -0.046 & 0.337 & 0.341 \\
\hline EH & & & & & & & & 1 & 0.415 & 0.287 & -0.282 & $0.590^{*}$ & -0.229 & -0.096 & 0.200 \\
\hline $\mathrm{Tp}$ & & & & & & & & & 1 & -0.137 & $-0.800^{\star}$ & $0.734^{*}$ & -0.483 & 0.070 & 0.168 \\
\hline SI & & & & & & & & & & 1 & 0.233 & -0.161 & 0.165 & -0.492 & -0.203 \\
\hline DO & & & & & & & & & & & 1 & $-0.750^{*}$ & 0.467 & 0.099 & 0.050 \\
\hline Gr & & & & & & & & & & & & 1 & $-0.804^{*}$ & 0.109 & 0.329 \\
\hline Sd & & & & & & & & & & & & & 1 & -0.218 & $-0.629^{*}$ \\
\hline Fn & & & & & & & & & & & & & & 1 & 0.359 \\
\hline OM & & & & & & & & & & & & & & & 1 \\
\hline
\end{tabular}

2006) to $32.3 \mathrm{~m}$ (May 2007) and marginal " $z$ " width ranged from $4.2 \mathrm{~m}$ (August 2006) to $20 \mathrm{~m}$ (June 2006). The shape of the meadow had no seasonal pattern, but exhibited constant movement on the substrate.

The length of the meadow (h) was inversely correlated to the widths. Spearman's correlation coefficients indicated negative correlations between " $h$ " and " $y$ " ( $r=-0.76 ; p=0.011)$ and between " $h$ " and " $z$ " $(r=-0.89 ; p=0.001)$. Moreover, a positive correlation was found between the " $y$ " and " $z$ " widths $(r=0.70$; $p=0.024)$. Most of time, the meadow was pushed toward the coastline, with larger widths and a smaller length (Fig. 6.1). On only two occasions (April 2006 and August 2006), the inverse occurred, when the meadow seemed to be influenced by a force parallel to the coastline (Fig. 6.2).

\section{Influence of environmental factors on biometry and biomass of Halodule wrightii}

Using non-correlated environmental variables (Table 2), the inflation factor determined in a canonical correlation analysis was above of acceptable limit
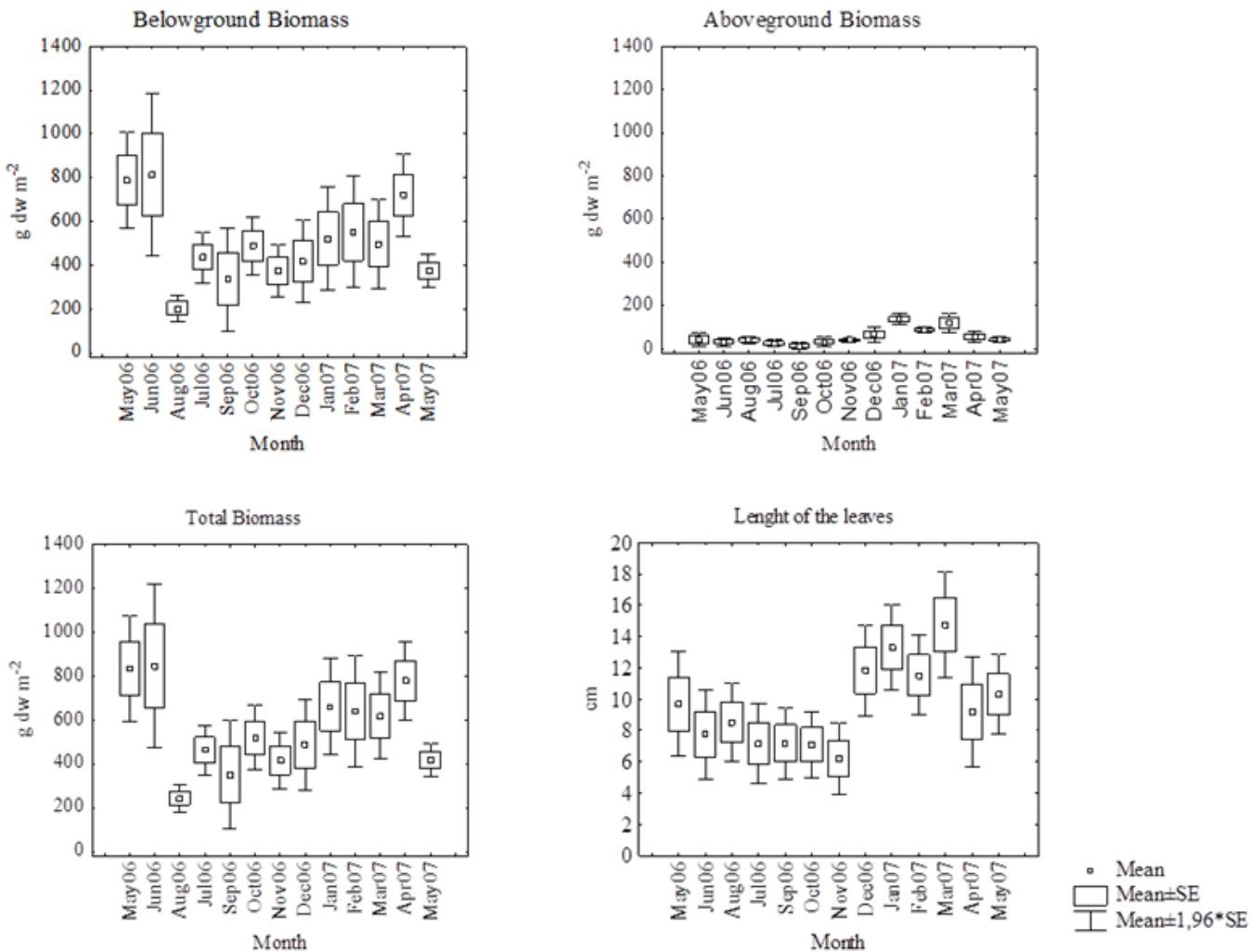

Figure 4 - Average values in the rainy and dry seasons of the leaves length, total biomass, belowground biomass, and aboveground biomass of the studied $H$. wrightii meadow, in Goiabeiras Beach, Northeastern Brazil. 


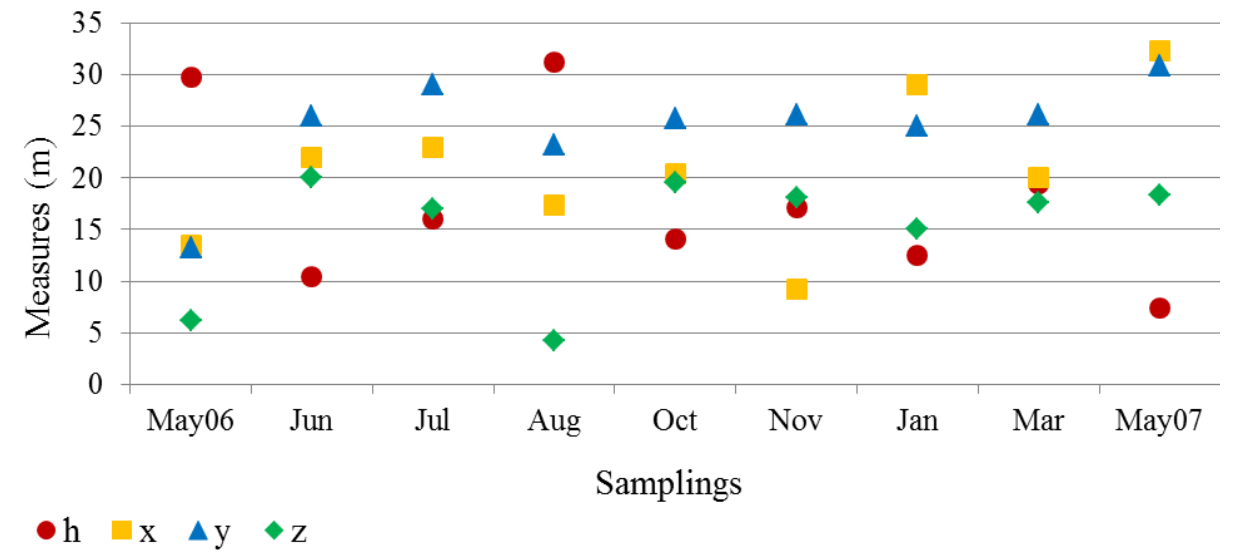

Figure 5 - Temporal variation of measures established on the Halodule wrightii meadow from Goiabeiras Beach, Ceará, Northeastern Brazil (2006-2007).

(10.0) (Table 3). In order to reduce these indices, wind velocity (which influence a number of physical variables) was removed out from the data set. The graph resulting from the CCA (Fig. 7) showed samples from April to September more disperse and the majority was around the upper right corner of the graph; and samples from October to February were near the lower left corner.

According to the CCA, abiotic variables explained $40 \%$ of all canonical axes and the correlation between morphological characters and environmental variables explained $78 \%$ of the variance on two first Axes, and $59 \%$ of the variance on Axis 1. Ignoring the abiotic variables, the biological data explained $30.3 \%$ of the data variability on Axis 1 . Waves height $(-0.313)$ and salinity $(-0.264)$ were the environmental variables most strongly correlated to Axis 1 ; temperature (0.326) and salinity $(0.313)$ were the variables most strongly correlated to Axis 2. Considering the same variables, a BIO-ENV analysis (Tab. 4) pointed out pluviometric

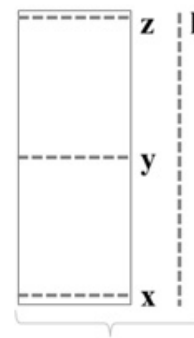

1
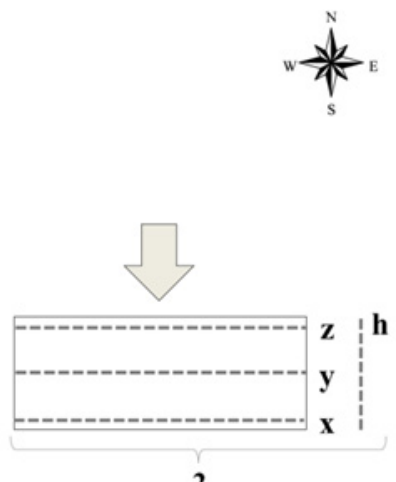

2

Coastline

Figure 6 - Effects of physical factors indicated by arrows on $H$. wrightii bed from Goiabeiras Beach, Northeastern Brazil. 1- meadow pushed perpendicularly to the coastline, with greater length than widths, as observed at the beginning of the study, probably influenced by a force parallel to the coastline; $\mathbf{2}$ - meadow conformed by a force perpendicular to the coastline, with length decreasing and widths increasing. precipitations, wind velocity, wave height, wave period and salinity $(r=0.226)$, and mainly precipitations, wind velocity and salinity ( $r=0.225)$, as the most important environmental variables that explained the variance of the samples.

\section{DISCUSSION}

Stronger winds in the dry season, acting mainly on the sedimentary characteristics, and probably the regular emersion, when salinity and temperature intensify their role on the plants, had an aggressive effect on the canopy and biomass of the studied $H$. wrightii meadow.

With the decrease in wind velocity during rainfall, the sediment exhibited greater stability, without great variations in grain size and percentages, and higher percentages of both $\mathrm{OM}$ and silt/clay. A number of studies suggest significant, positive influences from increase in silt/clay percentage. This cause a reduction in porosity, resulting in the accumulation of nutrients in the water column, which are absorbed by seagrasses through the leaves, as already observed for $\mathrm{H}$. wrightii and other species (Kenworthy et al., 1982; Huettel \& Gust, 1992; Huettel \& Rusch 2000; Koch, 2001).

Table 3 - Inflation factor values of environmental variables in a canonical correlation analysis considering all non-correlated variables (1) and inflation factor of these variables after remove wind speed out the model (2).

\begin{tabular}{lcc}
\hline \hline \multicolumn{1}{c}{ Variables } & 1 & 2 \\
\hline Precipitation (mm/month) & 19.1 & 4.2 \\
Wind speed (m/s) & 85.5 & - \\
Waves Height $(\mathrm{m})$ & 13.8 & 2.6 \\
Waves Period (s) & 26.7 & 2.2 \\
Water temperature $\left({ }^{\circ} \mathrm{C}\right)$ & 1.5 & 1.2 \\
Salinity (ppm) & 2.4 & 1.8 \\
Fines (\%) & 4.0 & 4.0 \\
MO (\%) & 2.3 & 2.3 \\
\hline \hline
\end{tabular}




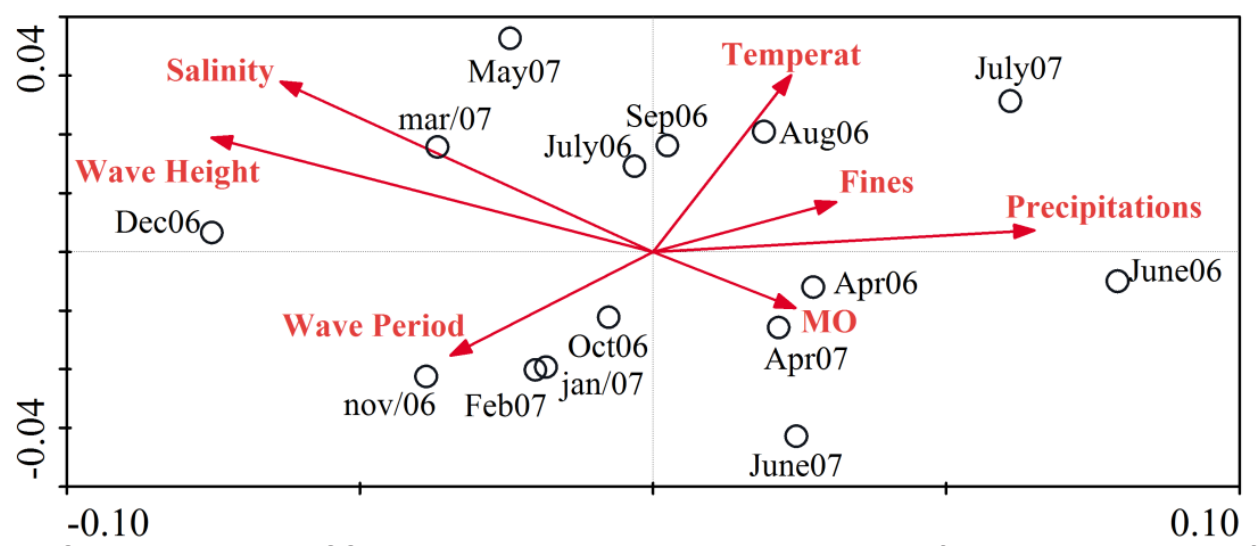

Figure 7 - Canonical Correlation Analysis (CCA) diagram and samples (months) dispersion of biometry and biomass of Halodule wrightii from Goiabeiras Beach, 2006-2007.

The calm waters that predominated in the rainy season were replaced with an increase in the intensity of the waves in the dry season due to the action of the wind and this may explain the correlation between waves and the variance of the samples. The increase in water movement consequently provided the input of medium-coarse sand into the meadow as well as the removal of fine sand and OM. Moreover, turbulence may have had a negative effect on the photosynthetic process. Winds may directly or indirectly influence several of these variables in shallow areas. Winds may directly or indirectly influence several of these variables in shallow areas. Besides regulate hydrodynamics, maintaining the heterogeneity of the seagrass landscape (Dawes, 1998; Robbins \& Bell, 2000; Fonseca et al., 2008). According to Clarke (1987), the direct impact of waves, in combination with currents, erodes the edges of the meadow. The action of physical factors on the shape of the studied bed may also be enhanced due to its small size.

Throughout the present study, the meadow was mainly influenced by a force perpendicular to the coastline, with direction compatible with the predominant winds (ESE), although the winds were not strong year round. The position of the meadow reversed on only two occasions, likely due to the greater temporary influence of longshore currents. In the region studied, longshore currents are driven by winds at $80^{\circ}$ (Morais, 1980) parallel to the coastline, with greater velocity in the dry season (Maia et al., 1998). Besides the physical

Table 4 - Best results of BIO-ENV analysis. Legend: PP - pluviometric precipitations; $\mathrm{WV}$ - wind velocity; $\mathrm{WH}$ - waves height; WP - waves period; SI - Salinity; WT - water temperature.

\begin{tabular}{ccc}
\hline \hline $\begin{array}{c}\text { Number of } \\
\text { variables }\end{array}$ & $\begin{array}{c}\text { Best variable } \\
\text { combinations }\end{array}$ & $\begin{array}{c}\text { Correlation } \\
(\boldsymbol{p} w)\end{array}$ \\
\hline 4 & $\mathrm{PP}-\mathrm{WV}-\mathrm{WH}-\mathrm{WP}-\mathrm{SI}$ & 0.226 \\
3 & $\mathrm{PP}-\mathrm{WV}-\mathrm{SI}$ & 0.225 \\
4 & $\mathrm{PP}-\mathrm{WH}-\mathrm{WT}-\mathrm{SI}$ & 0.223 \\
5 & $\mathrm{PP}-\mathrm{WV}-\mathrm{WH}-\mathrm{WT}-\mathrm{SI}$ & 0.222 \\
3 & $\mathrm{PP}-\mathrm{WH}-\mathrm{SI}$ & 0.222 \\
\hline \hline
\end{tabular}

impact, currents also exert an influence on the suspended sediment in the bed, the diffusion of dissolved gases to and from plants and nutrient exchange to and from the sediment-water interface (Gambi et al., 1990). Moreover, currents affect seagrass production, growth rate and photosynthesis (Fonseca \& Kenworthy, 1987 ) and likely exert an influence on the shape of the meadow.

Retraction and expansion events in the studied meadow were not seasonal, unlike observations of Robins \& Bell (2000) for meadows of $H$. wrightii and Thalassia testudinum Koenig et Sims in Tampa Bay (USA). Indeed, these phenomena were constant throughout the year, which is similar to findings reported by Oliveira et al. (1997) for a H. wrightii meadow in southeastern Brazil. However, retraction and expansion are dependent upon location, water depth, and seagrass species (Zieman, 1982; Clarke, 1987; Duarte \& Sand-Jensen, 1990; Robbins \& Bell, 2000). Robins \& Bell (2000) found that the overall expansion of seagrass was generally at the exterior margins of $H$. wrightii patches, with a small amount of loss and gain within the patches.

The events considered seasonal regarding the shape of the meadow studied were the clearance and colonization alternating of small patches, with the invasion of macroalgae within the intermatte channels, as cited for other $\mathrm{H}$. wrightii meadows along the coast of Brazil (Silva et al., 1987; Magalhães et al., 1997; Oliveira et al., 1997; Sordo et al., 2011). However, these events occurred during the dry season, unlike findings reported in the cited studies, where the winds act during the rainy season. Besides the subdivision into patches in the dry season, physical factors also led to the dislodgement of the oldest leaves, root and rhizome exposure and the burying of shallower parts of the meadow, with a consequent decrease in both biometry and biomass. Sordo et al. (2011) report cleared areas associated with the rainy season (when wind velocity is greater), accompanied by precipitation 
and an increase in wave action. Vulnerable places of the bed are more subject to erosion from waves, in combination with currents (Clarke, 1987; Den Hartog, 1971). This could include the oldest shoots and edges of the meadows.

The recorded retraction and expansion events were also not believed to be associated with reproduction or growth, as observed by Duarte \& Sand-Jensen (1990) for patches of Cymodocea nodosa (Ucria) Ascherson. The absence of flowers, fruits or seeds in the samples ruled out the possibility of sexual reproduction for explaining the increase/decrease in the meadow. In a nearby region, Laborel-Deguen (1962-63) found that the propagation of rhizomes was the most common reproductive event; these rhizomes may be carried by currents, yielding other meadows and ensuring both the propagation and survival of the species. According to Billingham et al. (2003), both biotic and abiotic factors are limiting to seed production and sexual recruitment in Zostera marina L. The authors add that clonal growth plays a more important role in the reproduction of this species at higher latitudes than in meadows near the equator. Based on the present findings, clonal growth may also be an important property for the maintenance of seagrass beds and the propagation of species submitted to strong hydrodynamics, which may exert a negative influence on sexual reproductive processes (pollination, establishment of seeds, etc.), regardless of latitude. However, sexual reproduction should be further investigated in the meadow studied to determine the role of climate changes and hydrodynamics in this process. Regarding to growth, these results show a well-defined seasonality of the seagrass, discarding the possibility of relation between the constant shape variations.

The indices of biometry and biomass in the meadow studied were above to some $H$. wrightii meadows (Creed, 1997; Oliveira et al., 1997; Boer, 2000) and similar to other meadows (Pulich, 1985; Dunton, 1994; Magalhães et al., 1997; Medina-Gómez \& Herrera-Silveira, 2006) around the world. At low spring tides, seagrasses are exposed to air, sunlight and the direct incidence of waves. According to Stapel et al. (1997), these factors may be responsible for the low development of the seagrass Thalassia hemprichii (Ehrenberg) Ascherson in Indonesia. Besides local conditions, a number of authors report that variations in biometry and biomass of $H$. wrightii are related to higher values when submerged, narrower leaves and lesser biomass in shallow waters, where these plants are influenced by tides, waves, insolation, exposure to ultraviolet radiation and air due to their sensitivity to dissection (Phillips, 1967; Laborel-Deguen, 1962-63; Phillips, 1967; Mcmillan, 1978; Koch \& Beer, 1996;
Magalhães et al., 1997; Oliveira et al., 1997; Stapel et al., 1997; Dawes, 1998; Koch, 2001).

Tropical seagrasses may be strongly influenced by tidal exposure and water motion (Erftemeijer \& Herman, 1994; Oliveira et al., 1997). In the studied meadow, the exposure also caused occurrences of burnt leaves during the dry season, when cloudiness decreased and sunlight hours increased. This phenomenon is known as "burning" (Erftemeijer \& Herman, 1994), suffering desiccation with deleterious effect (Waycott et al., 2007). Temperature and salinity were measured during tidal exposure, maybe justifying their correlation, although weak, to the variance of the samples, indicated both in the CCA and BIO-ENV.

Salinity and water temperature may exert a significant influence on reproductive and vegetative processes, such as flowering and biomass of $H$. wrightii (McMillan, 1978; Pulich, 1985; Dawes, 1998). Sordo et al. (2011) stress the major role of temperature in the expansion and regression of $H$. wrightii meadows at its southernmost limit of south Atlantic. In terms of climate change, it is highlighted that the sustainability of seagrasses depends on their adaptation to changes in salinity and chronic exposure to higher water temperatures, which alters seed germination, the formation of propagules, photosynthesis, growth and biomass (Short \& Neckles, 1999). Although varying little throughout the year, the influence of both temperature and salinity on the variance may be related to emersion of the meadow during low spring tides and this is a cause for concern in times of climate change for meadows in the same conditions. This phenomenon may be even stricter in tropical meadows and those with sporadic exposure. Thus, studies on the influence of environmental factors on vegetative and reproductive cycles in seagrasses in the natural environment may help provide solutions for possible harm in the future.

Furthermore, because of the strong influence of rains and windy patterns on other environmental variables studied here, this meadow might be strongly affected by the effects of global warming on the climate, decreasing the rainfall regime (Marengo, 2006) and duplicating the wind velocity up to 2100 (Pereira et al., 2013). In this context, future perspectives for the studied meadow are not the best. This is to be expected not only due to the influence of climate changes on salinity and temperature of the oceans, but also considering their actuation on the main meteorological factors that influence this meadow (rainfall and winds). The increase in sea level, in contrast, might at least minimize the effects of exposure and direct action of waves on the meadow during low tides, preserving some ecological and economical services of this meadow. 


\section{CONCLUSION}

The life cycle of the studied meadow tends to begin in the rainy season, when the leaves grow and the biomass increases, reaching peak values at the apex of this season. In contrast, along the dry season the winds act on the hydrodynamics and dislodge the oldest leaves of the seagrass, promoting decreasing of biometry and biomass.

Considering the main environmental factors studied herein, some meteorological factors (i.e. winds, precipitation and sunlight) have a greater potential to influence a number of other variables. Although varying little throughout the year, temperature and salinity played had a great role in the variance found in the $H$. wrightii meadow studied probably due to their sporadic exposure. Thus, further studies should consider the specific influence of these variables on reproductive events in $\mathrm{H}$. wrightii in the natural environment.

\section{AKNOWLEDGEMENTS}

Kcrishna V. de S. Barros would like to thank the Brazilian National Council of Technological and Scientific Development (CNPq) for her master's scholarship.

\section{REFERENCES}

Barros, K. V. S., Rocha-Barreira, C. A. \& Magalhães, K. M. 2013. Ecology of Brazilian seagrasses: Is our current knowledge sufficient to make sound decisions about mitigating the effects of climate change? Iheringia, Ser. Bot., 68(1): 163-178.

Barros, K. V. S., Ximenes, C. F., Carneiro, P. B. M., Rocha-Barreira, C. A. \& Magalhães, K. M. 2013. Influence of the shoot density of Halodule wrightii Aschserson from rocky and sandy habitats on associated macroalgal communities. Braz. J. Oceanogr., 61(4):205-214.

Billingham, M. R.; Reusch, T.B.H.; Alberto, F. \& Serrão, E.A. 2003. Is asexual reproduction more important at geographical limits? A genetic study of the seagrass Zostera marina in the Ria Formosa, Portugal. Mar. Ecol. Prog. Ser., 265: 77-83.

Boer, W. F. 2000. Biomass dynamics of seagrass and the role of mangrove and seagrass vegetation as different nutrient sources for an intertidal ecosystem. Aquat. Bot., 66: 225-239.

Brazilian National Bank of Oceanographic Data of The Brazilian Navy - Banco Nacional de Dados Oceanográficos da Marinha do Brasil - BNDO. 2006/2007. Tábua das Marés (Máximas e Mínimas diárias). Centro de Hidrografia da Marinha ( $\mathrm{CHM})$, Diretoria de Hidrografia e Navegação. Available on line in https://www.mar.mil.br/dhn/chm/tabuas/ index.htm, accessed a priceless number of times: 2006-2007.

Bulthuis, D. A. \& Woelkerling, W. J. 1983. Biomass accumulation and shading effects of epiphytes on the leaves of the seagrass, Heterozostera tasmanica in Victoria, Australia. Aquat. Bot., 16: 137-148.

Burdick, D.M. \& Kendrick, G.A. 2001. Standards for seagrass collection, identification and sample design. In: Short, F.T.; Coles, R.G. (Eds.). Global Seagrass Research Methods. Elsevier, Amsterdam. p. 79-100.

Clarke, S. M. 1987. Seagrass-sediment dynamics in Holdfast Bay: Summary. Safish., 11: 4-10.

Creed, J. C. 1997. Morphological variation in the seagrass Halodule wrightii near its southern distributional limit. Short Communication. Aquat. Bot., 59: 163-172.

Dawes, C. J. 1998. Marine Botany. 2a ed. John Wieley, New York. 408p.

Den Hartog, C. 1971. The dynamic aspect in the ecology of seagrass communities. Thalassia jugosl., 7(1): 101-112.

Dennison, W. C. \& Alberte, R. S. 1985. Role of daily light period in depth distribution of Zostera marina (eelgrass). Mar. Ecol. Prog. Ser., 25: 51-61.

Duarte, C. M. 2000. Marine biodiversity and ecosystem services: an elusive link. J. Exp. Mar. Biol. Ecol., 250(1-2): 117-131.

Duarte, C. M. 2002. The future of seagrass meadows. Environ. Conserv., 29(2): 192-206.

Duarte, C. M. \& Sand-Jensen, K. 1990. Seagrass colonization: patch formation and patch growth in Cymodocea nodosa. Mar. Ecol. Prog. Ser., 65: 193-200.

Dunton, K. H. 1994. Seasonal growth and biomass of the tropical seagrass Halodule wrightii in relation to continuous measurements of underwater irradiance. Mar. Biol., 120: 479-489.

Erftemeijer, P. L. A. \& Herman, P. M. J. 1994. Seasonal changes in environmental variables, biomass, production and nutrient contents in two contrasting tropical intertidal seagrass beds in South Sulawesi Indonesia. Oecologia, 99: 45-59.

Fonseca, M. S. \& Kenworth, W. J. 1987. Effects of currents on photosynthesis and distribution of seagrasses. Aquat. Bot., 27(1): 59-78.

Fonseca, M. S.; Kenworthy, W. J.; Griffith, E.; Hall, M. O.; Finkbeiner, M. \& Bell, S. S. 2008. Factors influencing landscape pattern of the seagrass Halophila decipiens in an oceanic setting. Estuar. Coast. Shelf Sci., 76: 163-174. 
Gambi, M.C.; Nowel, A. R. M. \& Jumars, P. A. 1990. Flume observations on flow dynamics in Zostera marina (eelgrass) beds. Mar. Ecol. Prog. Ser., 61(1-2): 159-169.

Gordon, D. M.; Grey, K. A.; Chase, S. C. \& Simpson, C. J. 1994. Changes to the structure and productivity of a Posidonia sinuosa meadow during and after imposed shading. Aquat. Bot., 47: 265-275.

Hemminga M. \& Duarte, C.M. 2000. Seagrass Ecology. Cambridge University Press, Cambridge. 298p.

Huettel, M. \& Gust, G. 1992. Impact of bioroughness on interfacial solute exchange in permeable sediments. Mar. Ecol., 89: 253-267.

Huettel, M. \& Rusch, A. 2000. Transport and degradation of phytoplankton in permeable sediment. Limnol. Oceanogr., 45: 534-549.

Brazilian Institute Of Meteorology - INPE (2006/2007) Database for Teaching and Research- BDMEP. Available on line in http://www.cptec.inpe.br/, accessed a priceless number of times: 2006-2007.

Jones, C.G.; Lawton, J.H. \& Shachak, M. 1994. Organisms as ecosystems engineers. Oikos, 69(3): 373-386.

Kenworthy, W. J.; Zieman, J. C. \& Thayer, G. W. 1982. Evidence for the influence of seagrasses on the benthic nitrogen cycle in a coastal plain estuary near Beaufort, North Carolina (U.S.A.). Oecologia, 54: 152-158.

Koch, E. W. 2001. Beyond light: physical, geological and geochemical parameters as possible submersed aquatic vegetation hábitat requirements. Estuaries, 24: 1-17.

Koch, E. W. \& Beer, S. 1996. Tides, light and distribution of Zostera marina in Long Island Sound, USA. Aquat. Bot., 53: 97-107.

Koch, M.S.; Schopmeyer, S.; Kihn-Hansen, C. \& Madden, C.J. 2007a. Synergistic effects of high temperature and sulfide on tropical seagrass. J. Exp. Mar. Biol. Ecol., 341: 91-101.

Koch, M.S.; Schopmeyer, S.; Kihn-Hansen, C.; Madden, C.J. \& Peters, J.S. 2007b. Tropical seagrass species tolerance to hypersalinity stress. Aquat. Bot., 86(1): 14-24.

Köppen, W. 1948. Climatologia: Un estudo de los climas de la Tierra. Fondo de Cultura Econômica, México. $479 \mathrm{p}$.

Laborel-Deguen, F. 1962-63. Nota Preliminar sobre Ecologia das Pradarias de Fanerógamas Marinhas nas Costas dos Estados de Pernambuco e da Paraíba. Trab. Inst. Oceanogr., 3-4(1): 39-50.

Longstaff, B. J. \& Dennison W. C. 1999. Seagrass survival during pulsed turbidity events: the effects of light deprivation on the seagrasses Halodule pinifolia and Halophila ovalis. Aquat. Bot., 65: 105-121.
Magalhães, K. M., Eskinzi-Leça, E. \& Moura-Junior, A. M. 1997. Morfometria e biomassa da fanerógama marinha Halodule wrightii Ascherson no litoral norte de Pernambuco. Trabs. Oceanogr., 25: 83-91.

Maia, L. P.; Jimenes, J. A; Serra, J. \& Morais, J. O. 1998. The coastline of Fortaleza City. A product of environmental impacts caused by Mucuripe harbor. Arq. Ciênc. Mar, 31(1-2): 93-100.

Maia, L. P.; Freire, G. S. S.; Morais, J. O.; Rodrigues, A. C. B.; Pessoa, P. R. \& Magalhães, S. H. O. 2001. Dynamics of coastal dunes at Ceará State, Northeastern Brazil: dimensions and migration rate. Arq. Ciênc. Mar, 34: 11-22.

Marbà, N.; Duarte, C. M.; Alexandre, A. \& Cabaço, S. 2004. How do seagrasses grow and spread. In: Borum, J.; Duarte, C. M.; Krause-Jensen, D. \& Greve, T. M. (Eds.) European Seagrasses: an introduction to monitoring and management. The Mand MS Project. pp. 11-18.

Marengo, J. A. 2006. Mudanças climáticas globais e seus efeitos sobre a biodiversidade: caracterização do clima atual e definição das alterações climáticas para o território brasileiro ao longo do século XXI. Ministério do Meio Ambiente, Brasília, 2006. 212 p.

Masini, R. J.; Anderson, P. K. \& McComb, A. J. A Halodule - dominated community in a subtropical embayment: physical environment, productivity, biomass and impact of dugong grazing. Aquat. Bot., 71: 179-197, 2001.

McMillan, C. 1978. Morphogeographic variation under controlled conditions in five seagrasses, Thalassia testudinum, Halodule wrightii, Syringodium filiforme, Halophila engelmannii and Zostera marina. Aquat. Bot., 4: 169-189.

Medina-Gómez, I. \& Herrera-Silveira, J. A. 2006. Primary production dynamics in a pristine groundwater influenced coastal lagoon of the Yucatán Peninsula. Cont. Shelf. Res., 26: 871-986.

Morais, J. O. 1980. Aspectos do transporte de sedimentos no litoral do município de Fortaleza, estado do Ceará, Brasil. Arq. Ciênc. Mar, 20(1-2): 71-100.

Morais, J. O. ; Freire, G. S. S.; Pinheiro, L. S.; Souza, M. J. N.; Carvalho, A. M.; Pessoa, P. R. S. \& Oliveira, S. H. M. 2006. Ceará. In: Muehe, D. (Org.) Erosão e Progradação do Litoral Brasileiro. Ministério do Meio Ambiente, Rio de Janeiro. 132$154 \mathrm{pp}$.

Oliveira, E. C.; Corbisier, T.N.; Eston, V.R. \& AmbrósioJúnior, O. 1997. Phenology of a seagrass (Halodule wrightii) bed on the southeast coast of Brazil. Aquat. Bot., 56: 25-33.

Orth, R. J.; Carruthers, T. J. B.; Dennison, W. C.; Duarte, C. M.; Fourqurean, J. W.; Heck, K. L.; 
Hughes, A. R.; Hendrick, G. A.; Kenworthy, W. J.; Olyarnik, S.; Short, F. T.; Waycott, M. \& Williams, S. L. 2006. A global crisis for seagrass ecosystems. Bioscience, 56: 987-996.

Pereira, E. B.; Martins, F. R.; Pes, M. P.; Segundo, E. I. C. \& Lyra, A. A. 2013. The impacts of global climate changes on the wind power density in Brazil. Renew. Energ., 49: 107-110.

Phillips, R. C. 1967. On species of the seagrass, Halodule, in Florida. Bull. Mar. Sci., 17: 672-676.

Pulich, W. M. 1985. Seasonal growth dynamics of Ruppia maritima L. and Halodule wrightii Aschers. in southern Texas and evaluation of sediment fertility status. Aquat. Bot., 23 (1): 53-66.

Preen, A. R. \& H. Marsh. 1995. Responses of dugongs to large-scale loss of seagrass from Hervey Bay, Queensland, Australia. Wildlife Res., 22: 507-519.

Robbins, B. D. \& Bell, S. S. 2000. Dynamics of a subtidal seagrass landscape: Seasonal and annual changes in relation to water depth. Ecology, 81: 1193-1205.

Rubegni, F., Franchi, E. \& Lenzi, M. 2013. Relationship between wind and seagrass meadows in a nontidal eutrophic lagoon studied by a Wave Exposure Model (WEMo). Mar. Pollut. Bull., 70: 54-63.

Ruiz, J. M. \& Romero, J. 2001. Effects of in situ experimental shading on the Mediterranean seagrass Posidonia oceanica. Mar. Ecol. Prog. Ser., 215: 107-120.

Short, F.T.; Carruthers, T.; Dennison, W. \& M. Waycott, M. 2007. Global seagrass distribution and diversity: a bioregional model. J. Exp. Mar. Biol. Ecol., 350: 3-20.

Short, F. T. \& Neckles, H. A. 1999. The effects of global climate change on seagrasses. Aquat. Bot., 63: 169-196.
Silva, R. L.; Pereira, S. M. B.; Oliveira-Filho, E. C. D. \& Eston, V. R. 1987. Structure of a bed of Gracilaria spp. (Rhodophyta) in northeastern Brazil. Bot. Mar., 30: 517-523.

Simeone, S.; de Muro, S. \& de Falco, G. 2013. Seagrass berm deposition on a Mediterranean embayed beach. Estuar. Coast. Shelf Sci., 135: 171-181.

Sordo, L.; Fournier, J.; Oliveira, V. M.; Gern, F.; Panizza, A. C. \& Lana, P. C. 2011. Temporal variations in morphology and biomass of vulnerable Halodule wrightii meadows at their southernmost distribution limit in the southwestern Atlantic. Bot. Mar., 54: 13-21.

Stapel, J.; Manuntun, R. \& Hemminga, M. A. 1997. Biomass loss and nutrient redistribution in an Indonesian Thalassia hemprichii seagrass bed following seasonal low tide exposure during daylight. Mar. Ecol. Prog. Ser., 148: 251-262.

Waycott, M.; Collier, C.; McMahon, K.; Ralph, p.; McKenzie, I.; Udy, J. \& Grech, A. 2007. Vulnerability of seagrasses in the Great Barrier Reef to climate change. In: Johnson, J.E. \& Marshall, P.A. (Eds.) Climate Change and the Great Barrier Reef: a vulnerability assessment. Townsville, Great Barrier Reef Marine Park Authority and Australian Greenhouse Office. p. 193-235.

Zieman, J. C. 1982. The ecology of the seagrasses of south Florida: a community profile. Washington, U.S.F.W.S., Office of Biological Services, 162p.

Submetido: Maio/2014 Revisado: Junho/2014 Aceito: Julho/2014 